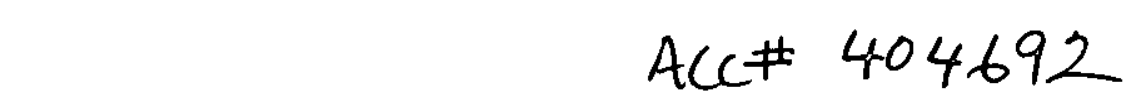

$A C C+404692$

DPST $-68 \cdot 30-1$

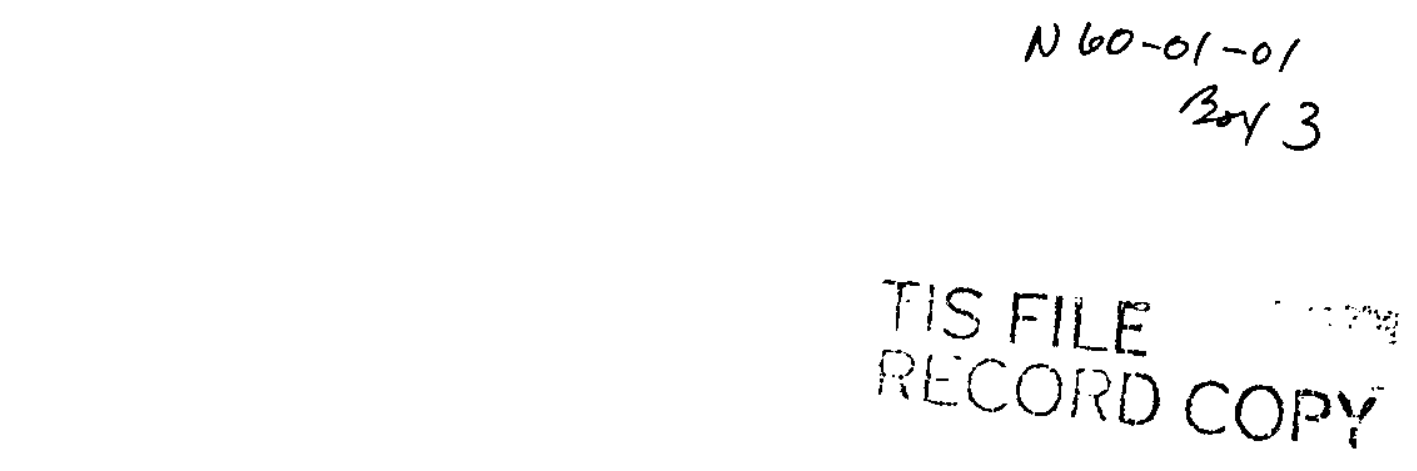

EFFECT OF THE

SAVANNAH RIVER PLANT

ON ENVIRONMENTAL RADIOACTIVITY

\title{
Semiannual Report
}

JULY THROUGH DECEMBER 1967

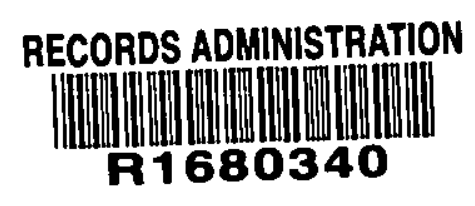

Prepored for the U. S. Atomic Energy Commission by the

Radiologieal Seiences Division of the Sovannah River Laboratory,

E. 1. du Pont de Nemours \& Co., the Commission's Prime Controctor

at the Sovannoh River Plant, Aiken, South Corolina 


\section{EFFECT OF THE SAVANNAH RIVER PLANT \\ ON ENVIRONMENTAL RADIOACTIVITY}

\section{Semiannual Report}

July through December 1967

\section{February 1968}

\section{CONTENTS}

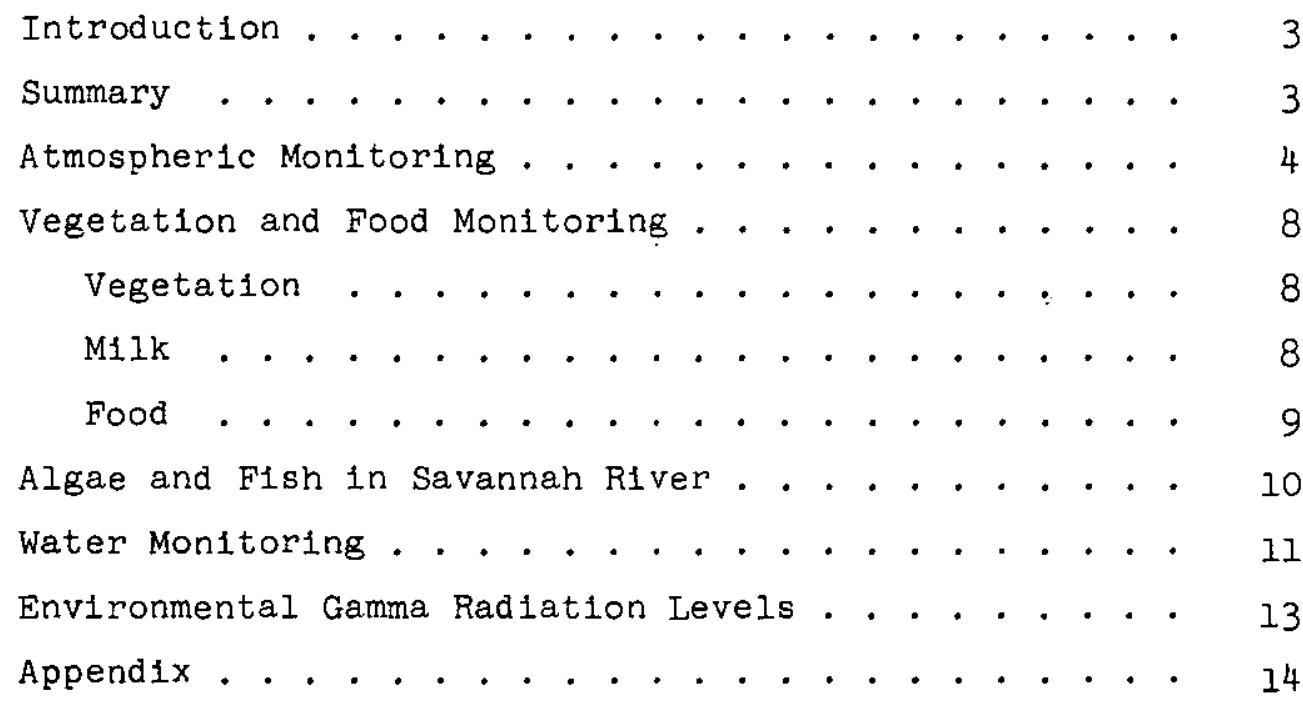




\section{INTRODUCTION}

The Savannah RIver Plant (SRP), bullt and operated for the Atomic Energy Commission by E. I. du Pont de Nemours and Company, occuples an area of 312 square miles along the Savannah River, 22 miles downstream from Augusta, Georgla. Production facilities include a fuel preparation area, four reactors, two fuel separations areas, and a heavy water production plant. A basic goal in plant operation is total containment of radioactive waste. Although some very low level gaseous and liquid wastes are discharged to the environment in controlled releases, dispersal is adequate to ensure environmental concentrations below recommended guides.

The Du Pont Environmental Monitoring Group has maintained a continuous monitoring program since 1951 (before plant startup) to determine the concentrations of radioactive materials in a $1200-$ square-mile area outside the plant. Included in this area are parts of Aiken, Barnwell, and Allendale counties in South Carolina, and Richmond, Burke, and Screven counties in Georgia. This suiveillance determines the magnitude and origin of any radioactivity above natural levels. Measured concentrations of radionuclides in air, wate $i^{2}$, and milk are compared with the Maximum Permissible Concentrations (MPC's) given in Chapter 0524 of the AEC Manual. (1) These MPC's are based on recommendations of the International Commission on Radiological Protection and of the Federal Radiation Council.

Sensitive instruments, which can detect traces of radioactive materials far below concentrations of hazard significance, are used to determine radioactivity in the environs. Plant-released radioactivity and atmospheric fallout are included in the reported concentrations. Maximum and minimum values given are for individual samples collected during the report period.

\section{SUMMARY}

This report, for the period July 1 through December 31, 1967 , presents the results of the environmental monitoring program for the atmosphere, vegetation, milk, and water. The quantity of radioactive waste released by the Savannah River Plant to its environs was, for the most part, too small to be distinguished from natural background radiation or was obscured by fallout from offsite sources.

(1) Title 10, Code of Federal Regulations, Part 20, "Standards for Protection Against Radiation" contains essentialiy the same standards as stated in the AEC Manual. 
Beta activity in a1r, which showed no relationship with plant operations, was about one-third of that for the same period of 1966 and was the lowest average ever observed at this site. Radioactive materials in fish flesh continued to be far below levels considered significant from a health standpoint. The average concentration of radionuclides in river water at Highway 301 did not exceed $0.25 \%$ of the Maximum Permissible Concentrations.

\section{ATMOSPHERIC MONITORING}

Concentrations of radioactive materials in the atmosphere were measured by biweekly analyses of air filters collected at five monitoring stations near the plant perimeter and ten stations around a circle of about 25 miles radius from the center of the plant (see Figure I). Deposition rates of radioactive materials

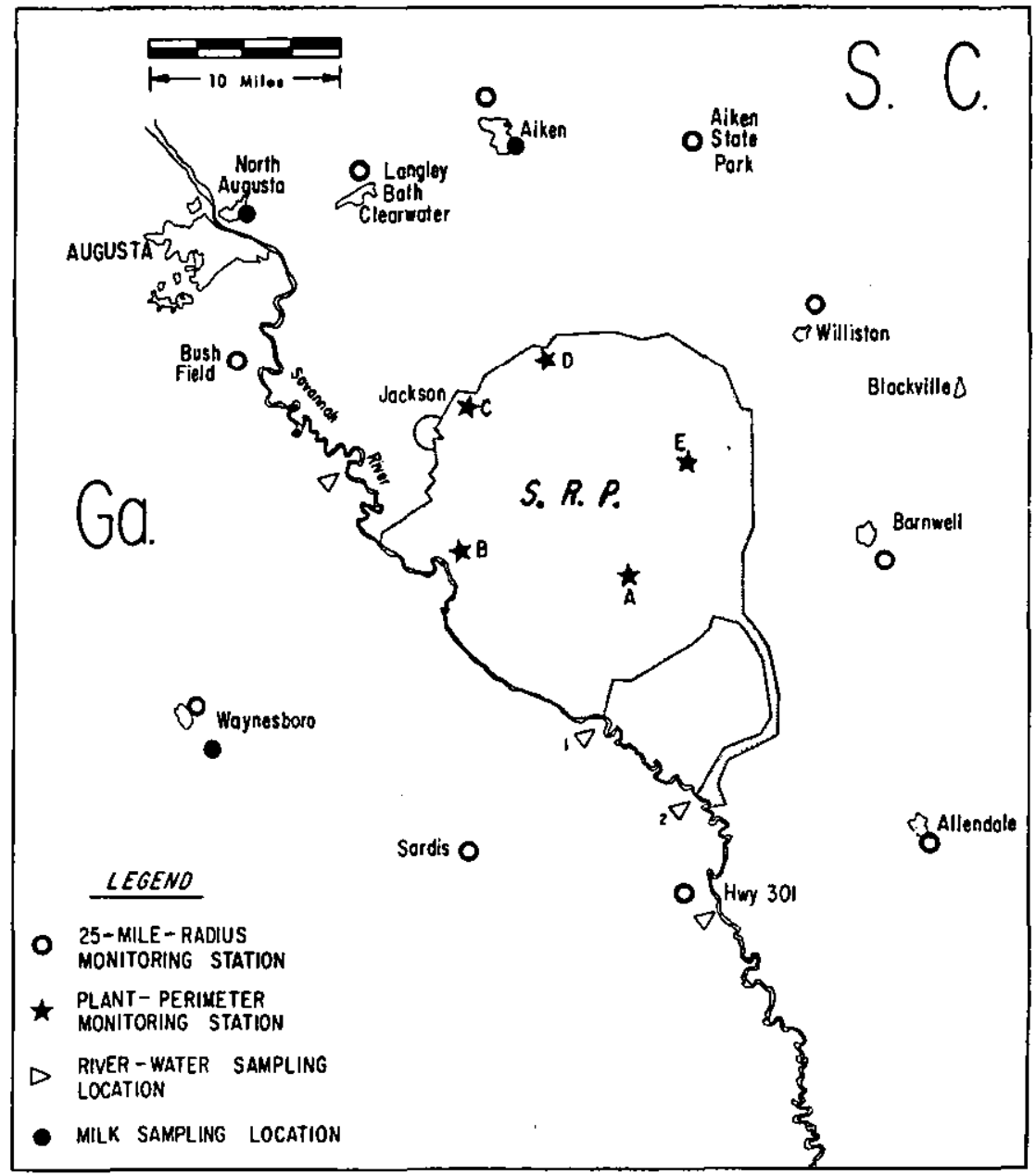

FIGURE I. SAMPLE COLLECTION POINTS 
at each station were also determined by monthly analyses of rainwater ion exchange columns (fallout collectors). The monitoring stations are spaced so that a significant release of airborne activity by SRP would be detected regardless of the prevailing wind. All stations operate continuously. Four additional air monttoring stations at Savannah and Macon, Georgia, and at Columbia and Greenville, South Carolina, are so distant from SRP that the effect of SRP operations is negligible; they are reference points for determining background activity levels (see Figure 2). This system permits comprehensive surveillance of atmospheric radioactivity and also makes it possible to differentiate between fallout and SRP releases.

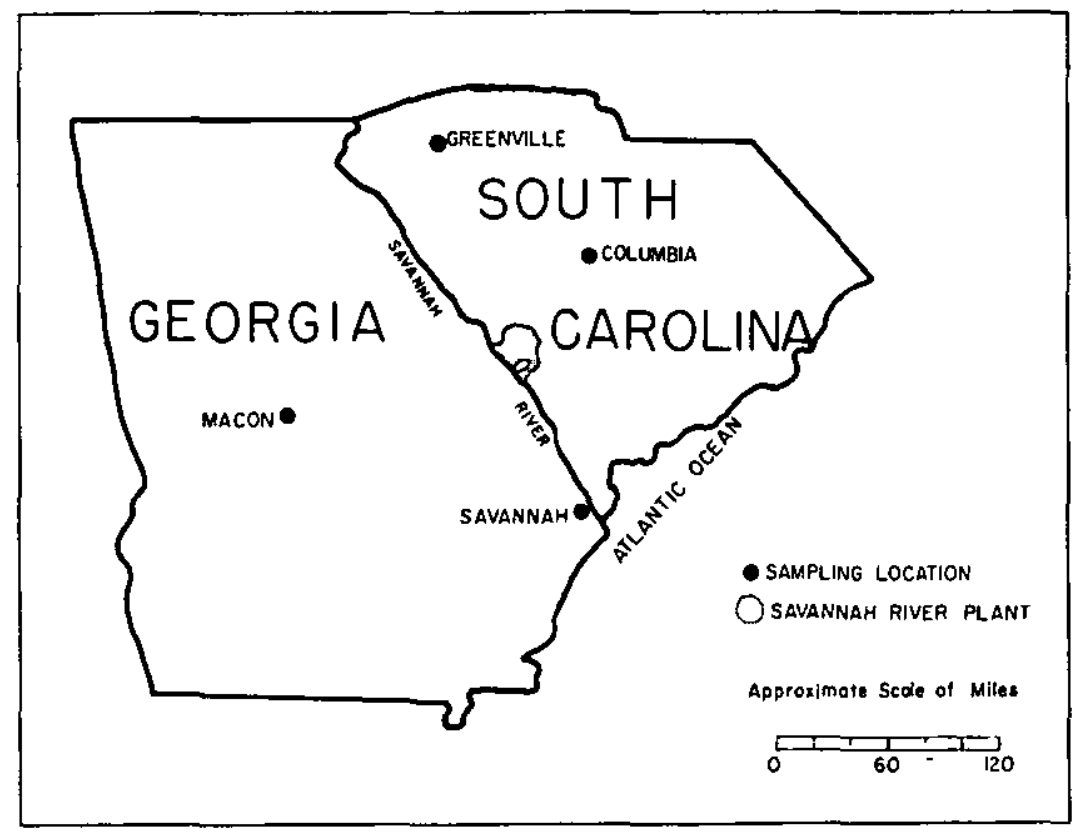

FIGURE 2. DISTANT AIR MONITORING STATIONS

The small amount of filterable beta activity released to the atmosphere, primarily from the fuel separations areas, was obscured by fallout. The influence of nuclear tests, which resumed in September 1961, is shown in Figure 3. The low levels of atmospheric activity are attributed to the moratorium on above-ground nuclear tests, which began $1 \bar{n} 1962$. The rise in early 1964 was the result of the anticipated spring increase in the mixing of the stratospheric debris into the troposphere. The average beta concentration for the last half of 1967 was the lowest ever observed at this site. 
Typical concentrations of gamma-emitting radionuclides in air during the six-month period are shown in the following table. The data were obtalned with a high-volume air sampler located at an atmospheric monitoring station at the Aiken airport. The major component, beryllium-7 ( $\left.{ }^{7} \mathrm{Be}\right)$, is a naturally occurring radionuclide formed by interaction of cosmic rays with oxygen and nitrogen in the upper atmosphere.

$\begin{array}{lr}\begin{array}{c}\text { RADIONUCLIDES } \\ \mathrm{pC1} / \mathrm{m}^{3}\end{array} & \text { IN AIR } \\ { }^{7} \mathrm{Be} & 0.095 \\ { }^{85} \mathrm{Zr}-{ }^{95} \mathrm{Nb} & .014 \\ { }^{137} \mathrm{Cs} & .002 \\ { }^{144} \mathrm{Ce} & .005\end{array}$

Radioactivity in air, determined from filter analyses, is shown in Table 2 of the Appendix. Concentrations of gamma emitters in routine samples were too low for reliable measurement. The JulyDecember 1967 concentrations of filterable beta activity $(0.03$ $\left.\mathrm{pCi} / \mathrm{m}^{3}\right)$ and alpha activity $\left(0.0006 \mathrm{pCi} / \mathrm{m}^{3}\right)$ in air were 0.03 and $0.8 \%$ of the respective MPC's. Tritium oxide concentrations in air, at the plant perimeter and at the 25-mile stations, did not exceed $0.1 \%$ of the MPC. Iodine-131 concentrations in routine alr samples were less than $0.02 \mathrm{pCi} / \mathrm{m}^{3}$, the lower detection limit, throughout the period.

Deposition of fallout during the last half of 1967 totaled 3.0 millicuries per square mile at plant perimeter locations and $2.5 \mathrm{mCl} / \mathrm{mi}^{2}$ at $25-\mathrm{mlle}$-radius locations; comparable values for the first half of 1967 were 59 and $53 \mathrm{mCl} / \mathrm{ml}^{2}$. 


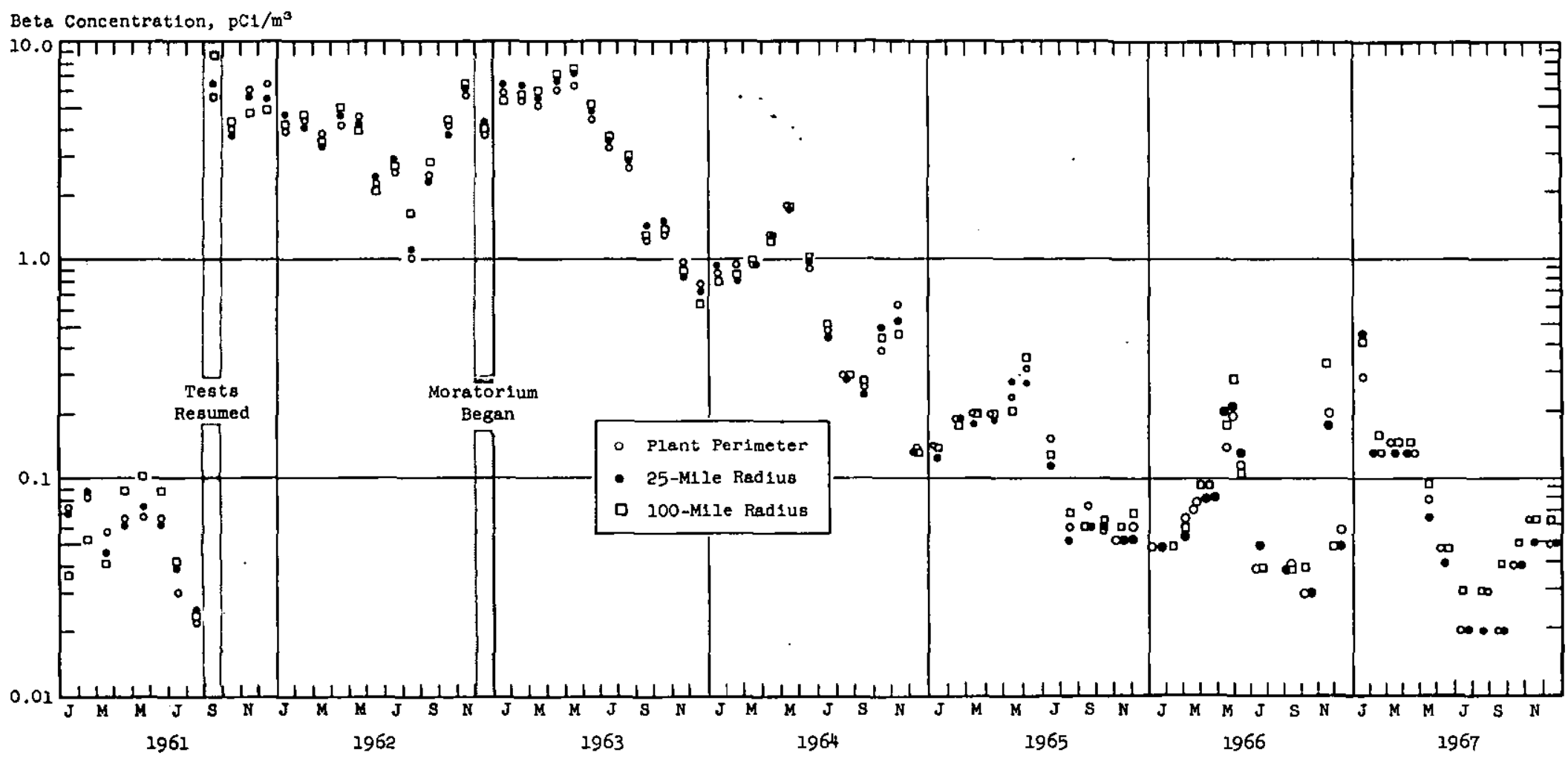

FIGURE 3. ATMOSPHERIC RADIOACTIVITY 


\section{VEGETATION AND FOOD MONITORING}

\section{VEGETATION}

Radioactive contamination of growing plants may result from sorption of radioactive materials from the soil or from follar deposition.

Bermuda grass was selected for analysis because of its importance as a pasture grass for dairy herds and its avallability during all seasons of the year.

Grass samples were collected at seven locations along the plant perimeter and at nine other locations along a 25-mile-radius route. (These are not designated on Figure 1.) Samples from each quadrant of the plant and of the surrounding area were composited for monthly analysis. Gamma-emitting radionuclides in grass samples (excluding $\left.{ }^{7} \mathrm{Be}\right)$ were from fallout. Alpha emitters averaged $0.1 \mathrm{pCl} / \mathrm{gram}$ at the plant perimeter and 25-mile-radius locations as compared to $0.2 \mathrm{pCl} / \mathrm{g}$ during the first half of 1967; gamma emitters averaged 4.8 and $5.3 \mathrm{pCi} / \mathrm{g}$, respectively, as compared to 32 and $37 \mathrm{pCi} / \mathrm{g}$ for the first half of 1967 . Radioisotop1c concentrations found in grass samples are presented in Table 4 of the Appendix. While the exact nature of the alpha activity decrease is not known, the change is commensurate with previously observed changes that appear to be seasonal.

MILK

M11k was sampled at three dairies within a 25 -mile radius of SRP, as shown in Figure 1. Samples were collected biweekly and were analyzed for tritium, radiocesium, and radiolodine.

Strontium-90 determinations were made quarterly. Milk produced in the area and sold by major distributors was also analyzed for these radionuclides. Results from analyzing milk for radioactivity during July-December 1967 are in Table 5 of the Appendix.

Iodine-131, strontium-90, and cesium-137 in milk are attributed to fallout. Average concentrations of the three radionuclides in milk were $<30 \mathrm{pCl} / 1$ of ${ }^{137} \mathrm{Cs}, 12 \mathrm{pCl} / 1$ of ${ }^{90} \mathrm{Sr}$, and $<5 \mathrm{pCl} / 1$ of ${ }^{131} \mathrm{I}$ compared to 30,20 , and $<7 \mathrm{pCi} / 1$, respectively, during the first half of 1967. These values, which are consistent with those reported by the U. S. Public Health Service for most sections of the United States, represented $0.2,3.0$, and $1.7 \%$ of the respective MPC's for water. Tritium in local milk, when present, is assumed to be associated with plant operations. The average tritium level was less than the sensitivity of the analysis, which allows detection of concentrations equivalent to $<0.1 \%$ of the MPC for water. 
FOOD

Farm produce, representing four food categories (grain, fruit, poultry, and leafy vegetables) were collected at fourteen localities in the six counties surrounding SRP (not shown on maps) during the summer and fall of 1967 . The 62 samples were analyzed by gamma spectrometry for ${ }^{141} \mathrm{Ce},{ }^{144} \mathrm{Ce},{ }^{131} \mathrm{I},{ }^{103} \mathrm{Ru},{ }^{106} \mathrm{Ru},{ }^{137} \mathrm{Cs},{ }^{85} \mathrm{Zr}-{ }^{85} \mathrm{Nb}$, and ${ }^{54} \mathrm{Mn}$. Radiochemical analyses were used for ${ }^{\circ 0} \mathrm{Sr}$ and alpha emitters (uranium and plutonium). With the exception of grains, all foods were prepared for analysis in a manner similar to that used to prepare them for eating. Peelings, seeds, and other nonedible parts were removed. Wheat, containing the whole grains only, and oats, containing both grains and husks, were processed unwashed. Results are summarized in Table 6 of the Append1x. Concentrations in some samples were too low for rellable measurement, and only results above the detection limit of the analyses are included.

SRP contributions to the levels of radioactivity in foods were so low in 1967 as to be indistinguishable from fallout. With the exception of ${ }^{137} \mathrm{Cs}$ and ${ }^{90} \mathrm{Sr}$, all radionuclides in food were near or below levels of detection. The amounts of ${ }^{90} \mathrm{Sr}$ and ${ }^{137} \mathrm{Cs}$ were slightly lower than during 1966; maximum concentrations were $0.62 \mathrm{pC} 1 / \mathrm{g}$ for ${ }^{90} \mathrm{Sr}$ in collards and $0.08 \mathrm{pCi} / \mathrm{g}$ for ${ }^{137} \mathrm{Cs}$ in grain. Alpha activity in food was about the same as in the 1966 samples. 


\section{ALGAE AND FISH IN SAVANNAH RIVER}

Fish, predominantly bream, and indigenous algae, primarily green (Vaucherla) and blue-green (Phormidium), were collected weekly upstream from, adjacent to, and downstream from the Savannah River Plant. Determination of radionuclides in algae is important because algae concentrate certain radionuclides and also because of the role of algae in the food cha1n of aquat1c organisms. Data from analyses of $\mathrm{flsh}$ and algae samples are in the following table. Beta concentrations in algae and fish adjacent to and downstream from SRP Indicate some minor contribution by SRP. Although measurably higher than similar material collected at the control station 3 miles upstream from SRP, the slight increase is of no blological significance.

Sampling Polnt

3 miles upstream from plant (control)

Along plant boundary

10 miles downstream

from plant (at

Highway 301 crosing)
NONVOLATILE BETA ACTIVITY IN SAVANNAH RIVER AQUATIC SPECIMENS ${ }^{a}$
F1sh, $\mathrm{pC1/g}$ (wet wt)
No. of $\frac{\text { Bone }}{\text { Samples Max M1n Avg }}$ Max M1n Avg

Samples Max M1n Avg

$$
\begin{array}{llll}
8 & 25 & 9 & 17
\end{array}
$$$$
15 \quad 450 \quad 20 \quad 150
$$

$$
62
$$$$
43
$$

$$
66
$$$$
77
$$

$\begin{array}{rr}3 & 17 \\ 11 & 24\end{array}$

49

25

14

18
$71 \quad 27 \quad 42$
47
53

a Sensitivity of analysis varied due to differing sample size.

In addition to nonvolatile beta analyses, specific radionuclide analyses were made on algae and fish collected from the Savannah River. Radiocesium and radiostrontium were found consistently in river algae; whereas cerium-141,144, chromium-51, zirconium-95n1oblum-95, manganese-54, zinc-65, and cobalt-60 were detected less frequently. Also, radiostrontium (Max: $18 \mathrm{pCl} / \mathrm{g}$, wet welght) was detected In bone tissue of river flsh, and radiocesium (Max: 41 $\mathrm{pC1} / \mathrm{g}$, wet weight) was detected in the flesh tissue. Radiozinc and phosphorus-32 were detected less frequently in these tissues. The maximum concentrations of ${ }^{32} \mathrm{P}$ detected in bone and flesh t1ssues of river f1sh were 102 and $17 \mathrm{pC1} / \mathrm{g}$, respect1vely. 


\section{WATER MONITORING}

The plantsite is drained by five streams that flow several miles through the reservation before reaching the river (see F1gure 4). In January 1965, the Beaufort-Jasper Water Author1ty began operation of a new treatment facility to furnish sanitary water, partially supplied from the Savannah River, to most of Beaufort County, South Carolina. Water is supplied through a new canal from the river at a location about 90 miles below the Savannah River Plant. The c1ty of Savannah also supplements 1ts domest1c well water supply with river water during perlods of peak demand.

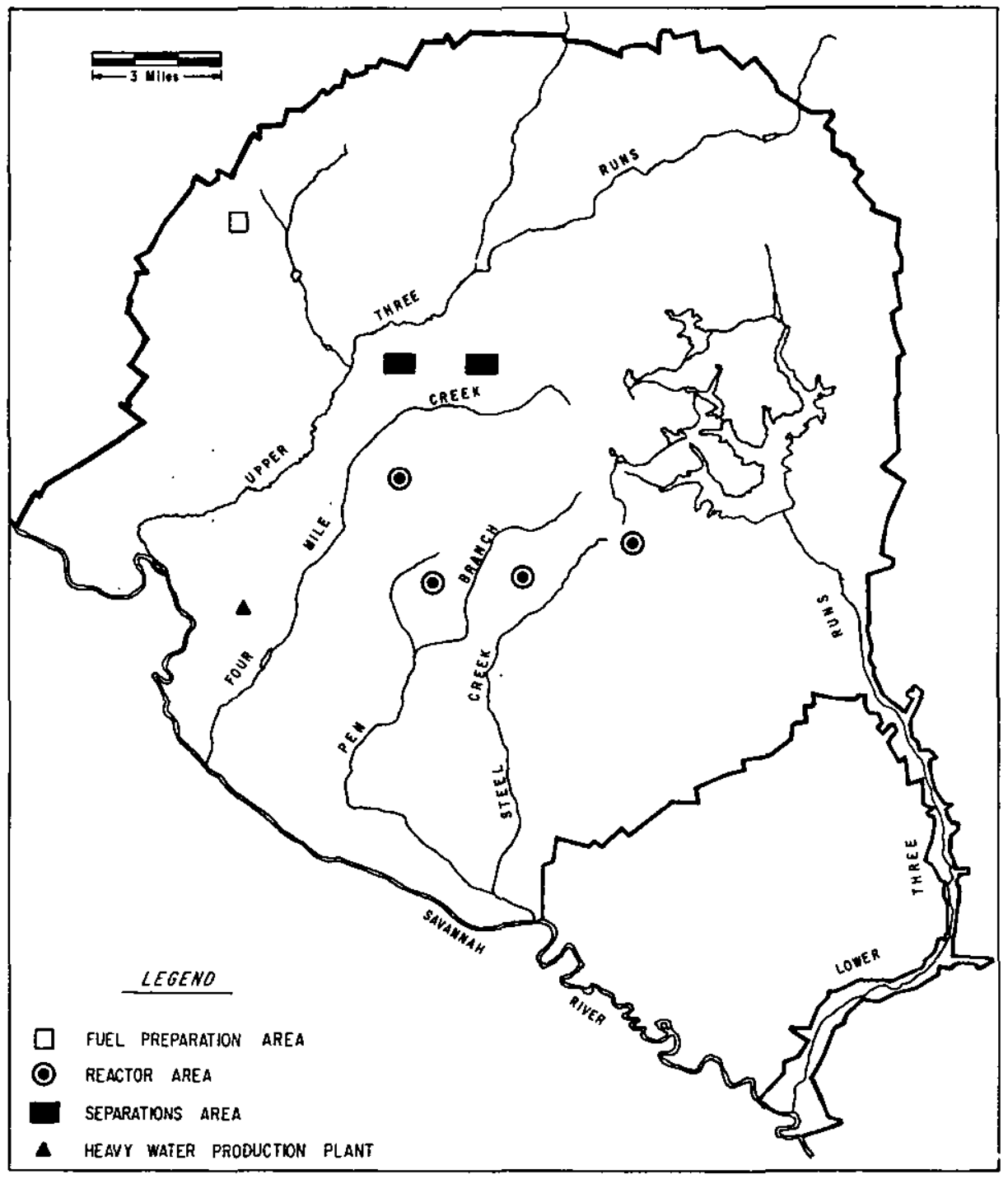

FIGURE 4. SRP PRODUCTION AREAS AND EFFLUENT STREAMS 
Communities near SRP get domest1c water from deep wells or surface streams. Public water supplies from 14 surrounding towns were collected and analyzed in october. There was no evidence that SRP contributed radioactivity to drinking water supplies; concentrations of alpha activity $(1.2 \mathrm{pCl} / 1)$ and beta activity $(6 \mathrm{pCl} / 1)$ were essentially the same as those observed before plant startup. Data from analyses of all public water samples are in Table 7 of the Appendix..

RIver water, analyzed weekly, was sampled continuously at four locations, as shown in Figure 1. Concentrations of alpha and nonvolatile beta emitters in river water for the past year are summarized in the following table; average concentrations of specific radionuclides found in river water during JulyDecember 1967 are in Table 8 of the Appendix.

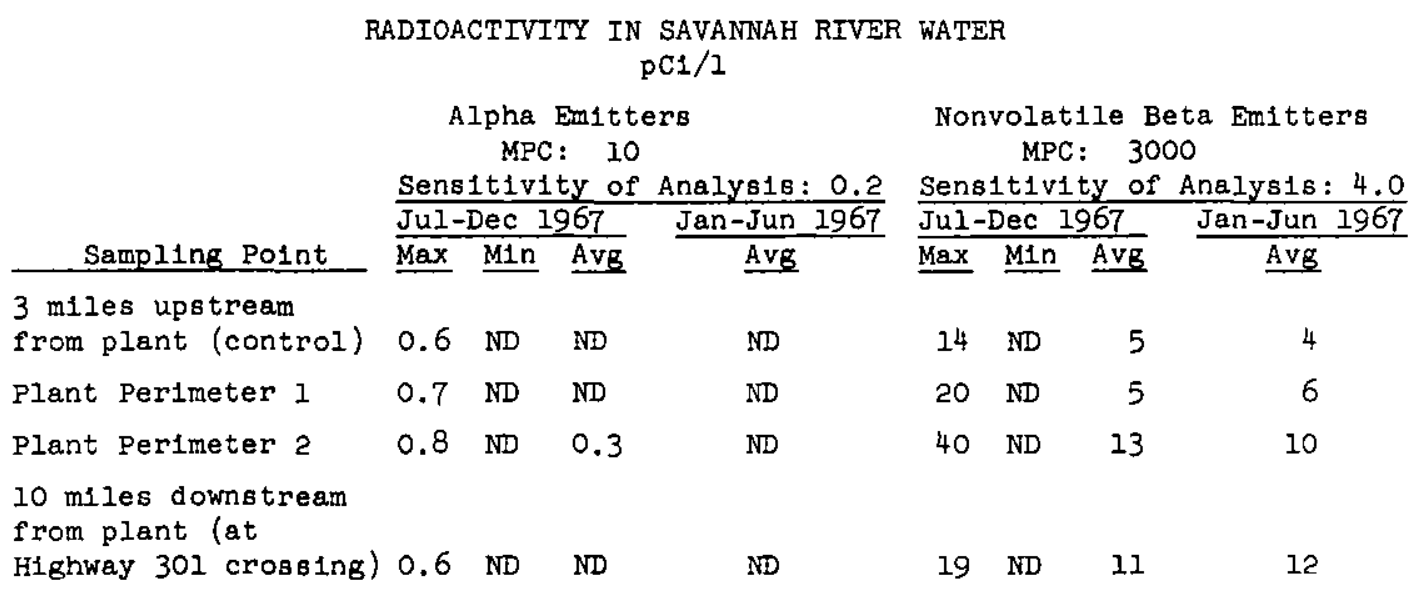

ND Less than sensitivity of analysis.

Trit1um, and trace amounts of ceslum-137, neptunium-239, lodine-131, chromium-51, stront1um-89 and strontlum-90, released malnly from reactor areas, were the radionuclides of SRP origin detectable in river water at the downstream location. ${ }^{90} \mathrm{Sr}$ and tritium from worldwide fallout were also detected in river water upstream from SRP. Average concentrations of all radionuclides found in river water during July-December 1967, as shown in Table 7 of the Appendix, were only small fractions of the permissible concentrations. The tritium concentrations in raw water collected from the Beaufort-Jasper Water Plant averaged $4000 \mathrm{pC1} / 1$ (0.1\% MPC) during the s1x-month report period. The annual radiation exposure of an Individual in this population due to the consumption of water contalning the very low concentration of tritium is only $0.4 \mathrm{mrem}$. The radiation dose was determined by analysis of urine (99 samples) collected from Beaufort residents during 1967. 
Tritium, a beta emitter and the most abundant radionuclide released to the river, is produced by neutron irradiation of heavy water moderator in the reactors. ${ }^{51} \mathrm{Cr}$, the second most abundant radionuclide released to the river, is produced by neutron irradiation of stable chromium (a component of the stainless steel used In reactor parts). Tritium and ${ }^{51} \mathrm{Cr}$ are among the least dangerous of all radionuclides because nelther concentrates in body tissues. The tritium and ${ }^{51} \mathrm{Cr}$ concentrations in river water averaged 0.25 and $0.0003 \%$ MPC, respectively.

\section{ENVIRONMENTAL GAMMA RADIATION LEVELS}

Monthly measurements of environmental gamma radiation were made with thermoluminescent dosimeters. The July-December 1967 data in the following table are characteristic of measurements observed at individual stations for the past several years.

ENVIRONMENTAL GAMMA RADIATION milliroentgens per 24 hours

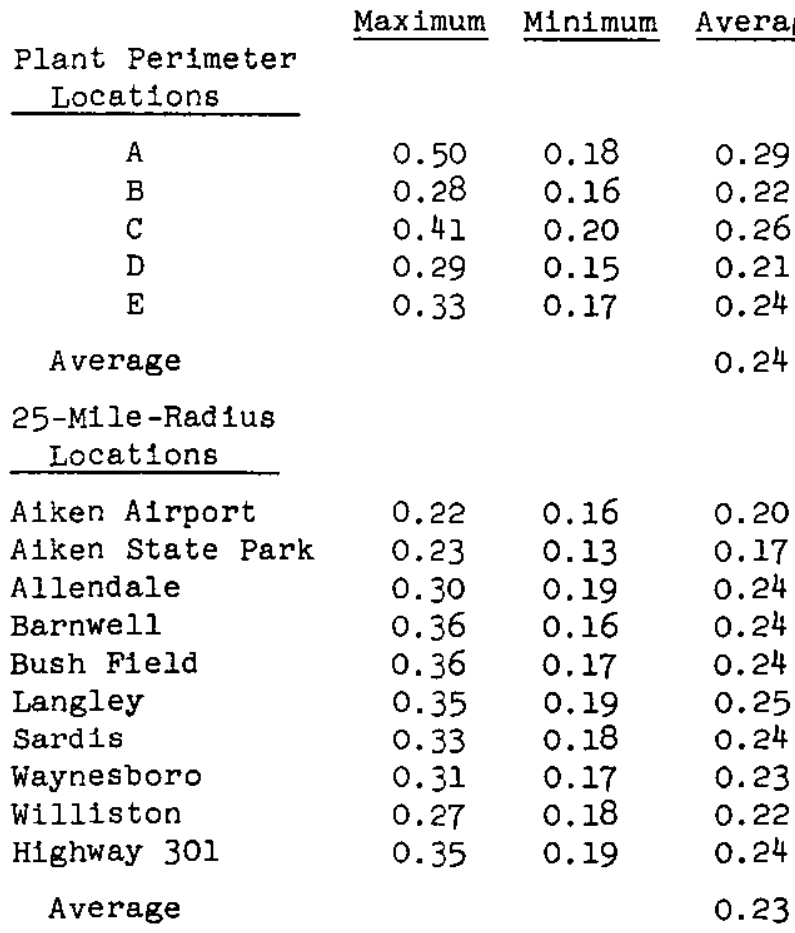




\section{APPENDIX}

TABLE 1

MAXIMUM PERMISSIBLE CONCENTRATION ${ }^{a}$

MPC

\begin{tabular}{|c|c|c|}
\hline \multirow[b]{2}{*}{ Radionuclide } & \multicolumn{2}{|c|}{ MPC } \\
\hline & $\begin{array}{c}\text { In Water, } \\
\mathrm{p} C 1 / 1\end{array}$ & $\begin{array}{l}\text { In } \mathrm{A} 1 \mathrm{r}, \\
\mathrm{pC1} / \mathrm{m}^{3}\end{array}$ \\
\hline Alpha & 10 & 0.07 \\
\hline Nonvolatile beta & 3,000 & 100 \\
\hline Trittum & $3,000,000$ & 200,000 \\
\hline${ }^{239} \mathrm{~Np}$ & 100,000 & 3,000 \\
\hline${ }^{131} \mathrm{I}$. & 300 & 100 \\
\hline${ }^{14} 0^{\circ} \mathrm{Ba}-{ }^{140} \mathrm{La}$ & 20,000 & 1,000 \\
\hline $137 \mathrm{Cs}$ & 20,000 & 2,000 \\
\hline${ }^{144} \mathrm{Ce}$ & 10,000 & 200 \\
\hline${ }^{103,108} \mathrm{Ru}$ & 10,000 & 200 \\
\hline${ }^{95} \mathrm{Zr-}{ }^{85} \mathrm{Nb}$ & 60,000 & 1,000 \\
\hline${ }^{65} \mathrm{Zn}$ & 100,000 & 2,000 \\
\hline${ }^{\circ} \mathrm{CO}$ & 50,000 & 300 \\
\hline${ }^{8 \theta} \mathrm{Sr}$ & 3,000 & 300 \\
\hline${ }^{\circ} \mathrm{Sr}$ & 400 & . 40 \\
\hline${ }^{54} \mathrm{Mn}$ & 100,000 & 1,000 \\
\hline${ }^{31} \mathrm{Cr}$ & $2,000,000$ & 80,000 \\
\hline
\end{tabular}

a Increases in magnitude of tabulated MPC's over those of previous publications reflect the latest recommendation of the International Commission on Radiological Protection. 
TABLE 2

RADIOACTIVITY IN AIR (FILTER ANALYSIS)
$\mathrm{pCi} / \mathrm{m}^{3}$

\begin{tabular}{|c|c|c|c|}
\hline $\begin{array}{c}\text { Alpha Enitters } \\
\text { (multiply by } 10^{-3} \text { ) }\end{array}$ & $\begin{array}{r}\text { Nonvolat } \\
\text { Emit }\end{array}$ & $\begin{array}{l}\text { t1le Beta } \\
\text { tters }\end{array}$ & \\
\hline MPC: 70 & MPC: & 100 & Specific \\
\hline Sensitivity of Analys1s:0.3 & Sensitivity of & f Analysis:0 & Radionuclides in \\
\hline Min & Max & Avg & Composite Samples \\
\hline
\end{tabular}

Plant Perimeter

Sampling Points

\begin{tabular}{|c|c|c|c|c|c|c|c|c|}
\hline A & 1.3 & 0.3 & 0.7 & 0.07 & 0.02 & 0.03 & $80,80 \mathrm{Sr}$ & $<0.005$ \\
\hline B & 1.2 & ND & .7 & .07 & ND & .03 & ${ }^{137} \mathrm{Cs}$ & $<.006$ \\
\hline $\mathrm{C}$ & 2.3 & .4 & 1.0 & .05 & .02 & .04 & $141,144 \mathrm{Ce}$ & $<.01$ \\
\hline D & $1: 9$ & ND & .9 & .10 & .02 & .04 & & \\
\hline$E$ & 1.5 & ND & .7 & .06 & .02 & .03 & ${ }^{85} \mathrm{Zr}-{ }^{85} \mathrm{Nb}$ & $<.02$ \\
\hline erage & & & 0.8 & & & 0.03 & & \\
\hline
\end{tabular}

25-M1le-Rad1us

Sampling Points

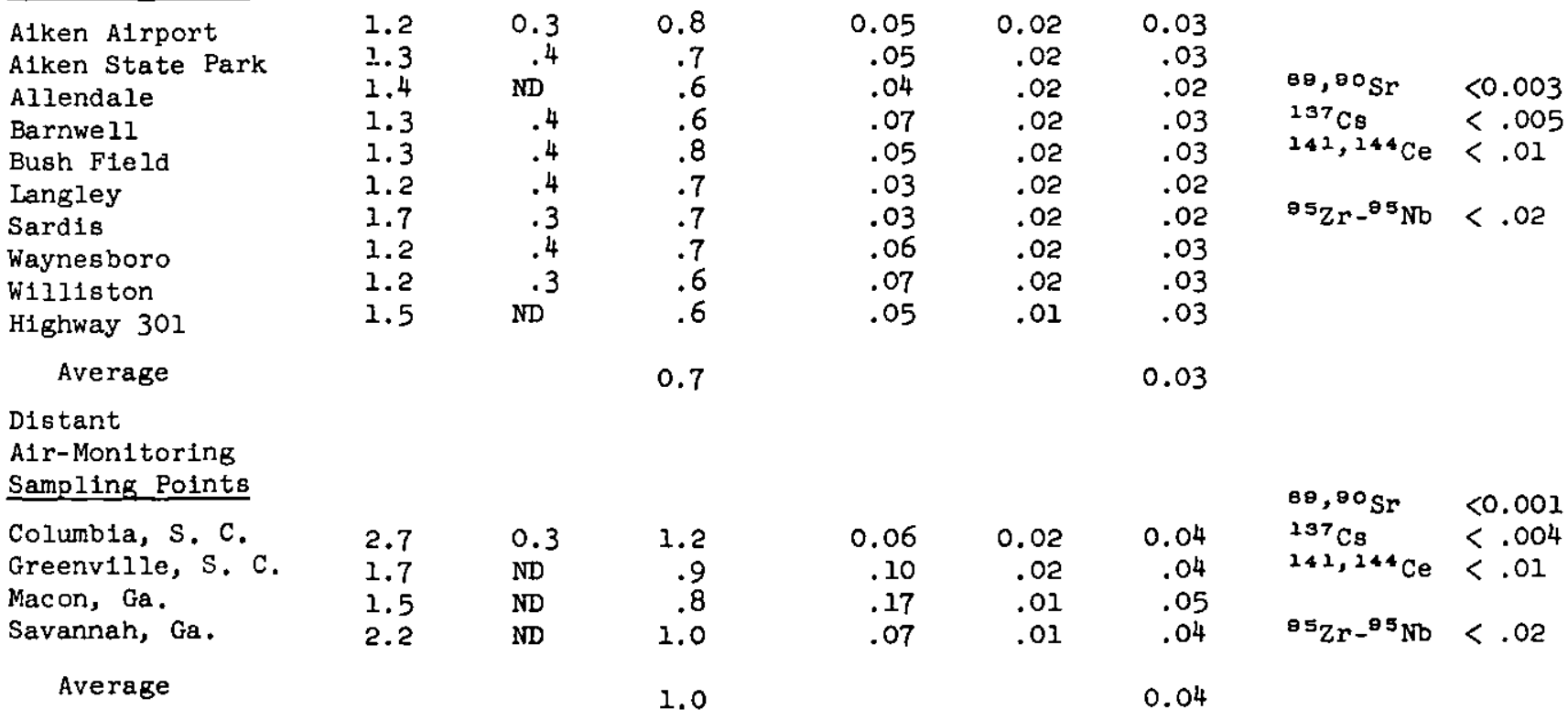

ND Less than sensitivity of analysis. 
TABLE 3

TOTAL FALLOUT DEPOSITED

$\mathrm{mC} 1 / \mathrm{m}^{2}$

\begin{tabular}{|c|c|c|c|c|c|c|c|}
\hline $\begin{array}{l}\text { Plant Perlmeter } \\
\text { Sampling Polnts }\end{array}$ & $\begin{array}{c}\text { Alpha } \\
\text { Em1tters } \\
\end{array}$ & ${ }^{\theta \theta} \mathrm{Sr}$ & ${ }^{80} \mathrm{Sr}$ & ${ }^{237} \mathrm{Cs}$ & $142,244 \mathrm{Ce}$ & ${ }^{85} \mathrm{Zr}-{ }^{85} \mathrm{Mb}$ & ${ }^{7} \mathrm{Be}^{\mathrm{b}}$ \\
\hline $\begin{array}{l}\mathrm{A} \\
\mathrm{B} \\
\mathrm{C} \\
\mathrm{D} \\
\mathrm{E}\end{array}$ & $\begin{array}{l}7.9 \\
4.8 \\
4.7 \\
5.2 \\
6.9\end{array}$ & $\begin{array}{c}0.3 \\
.5 \\
.1 \\
\mathrm{ND} \\
.2\end{array}$ & $\begin{array}{r}0.6 \\
.6 \\
.7 \\
.9 \\
.8\end{array}$ & $\begin{array}{r}1.8 \\
2.4 \\
1.1 \\
1.5 \\
.9\end{array}$ & $\begin{array}{l}\text { ND } \\
\text { ND } \\
\text { ND } \\
1.5 \\
\text { ND }\end{array}$ & $\begin{array}{c}0.5 \\
\text { ND } \\
.3 \\
.2 \\
.4\end{array}$ & $\begin{array}{l}41.8 \\
31.9 \\
24.4 \\
36.9 \\
23.7\end{array}$ \\
\hline \begin{tabular}{l}
\multicolumn{1}{c}{ Average } \\
25-M1le-Radius \\
Sampling Points
\end{tabular} & 5.9 & 0.2 & 0.7 & 1.5 & 0.3 & 0.3 & 31.7 \\
\hline $\begin{array}{l}\text { A1ken Alrport } \\
\text { A1ken State Park } \\
\text { Allendale } \\
\text { Bariwell } \\
\text { Bush Field } \\
\text { Langley } \\
\text { Sardis } \\
\text { Waynesboro } \\
\text { W1lliston } \\
\text { H1ghway } 301\end{array}$ & $\begin{array}{l}3.3 \\
5.0 \\
4.2 \\
1.4 \\
3.8 \\
6.8 \\
3.6 \\
5.0 \\
8.0 \\
4.8\end{array}$ & $\begin{array}{l}\mathrm{ND} \\
\mathrm{ND} \\
.8 \\
.7 \\
\mathrm{ND} \\
.3 \\
.3 \\
.2 \\
\mathrm{ND} \\
0.4\end{array}$ & $\begin{array}{l}0.4 \\
.8 \\
.3 \\
.3 \\
.7 \\
.4 \\
.5 \\
.4 \\
.5 \\
.5\end{array}$ & $\begin{array}{r}0.7 \\
.7 \\
.3 \\
\mathrm{ND} \\
1.8 \\
1.3 \\
2.5 \\
1.2 \\
.3 \\
1.7\end{array}$ & $\begin{array}{l}1.6 \\
\mathrm{ND} \\
\mathrm{ND} \\
1.5 \\
\mathrm{ND} \\
\mathrm{ND} \\
\mathrm{ND} \\
\mathrm{ND} \\
\mathrm{ND} \\
1.4\end{array}$ & $\begin{array}{c}0.2 \\
.6 \\
.3 \\
\mathrm{ND} \\
.4 \\
.5 \\
.9 \\
\mathrm{ND} \\
\mathrm{ND} \\
.2\end{array}$ & $\begin{array}{l}34.0 \\
19.7 \\
15.8 \\
5.8 \\
23.2 \\
30.4 \\
18.6 \\
16.4 \\
20.1 \\
20.0\end{array}$ \\
\hline Average & 4.6 & 0.3 & 0.5 & 1.0 & 0.4 & 0.3 & 20.4 \\
\hline
\end{tabular}

a Multiply by $10^{-2}$

b A natural radionuclide (see page 6 ).

ND Less than sensitivity of analysis.

TABLE 4

RADIOACTIVITY ON VEGETATION

pC1/g (dry we1ght)

\begin{abstract}
Alpha

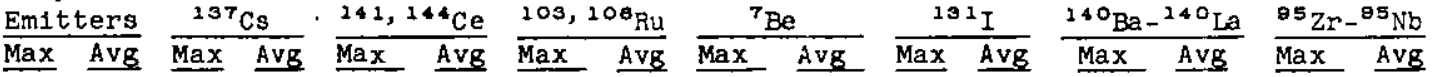

Plant perimeter

(7 locations)

$0.4 \quad 0.1 \quad 1$.

ND ND ND 4.4

$\begin{array}{lllll}3.5 & \text { ND ND ND ND } 2.8\end{array}$

0.9

25-mile radius

(7 locations)

1.00 .10 .8

.80.

ND ND ND

ND 5.2

$4.1 \mathrm{ND} N \mathrm{ND}$

ND ND

$2.6 \quad 0.9$

Sensitivity

of analysis

0.10

0.3

1.0

1.4

3.0

0.2

6.0

0.5

ND Less than sensitivity of analysis. 
TABLE 5

RADIOACTIVITY IN MILK

pC1/1

Tritium

$\frac{\text { MPC: 3,000,000 }}{\text { Max Min Avg }}$

Strontium-90 Iodine-131 MPC: 400 MPC : 300

Ces1um-137

Max Min Avg Sept Dec

Max Min Avg

Local Dairies

Alken

North Augusta

Waynesboro

$\begin{array}{ccc}5,000 & \mathrm{ND} & \mathrm{ND} \\ 8,000 & \mathrm{ND} & \mathrm{ND} \\ 7,000 & \mathrm{ND} & \mathrm{ND} \\ 6,000 & \mathrm{ND} & \mathrm{ND} \\ & 3000 & \end{array}$

$13 \quad 16$

ND ND ND ND ND ND

Major distributors ${ }^{\mathrm{a}}$

Sensitivity of analysis

ID

121

$910 \quad$ ND

1.0

ND ND ND ND

ND ND

ND ND

ND Less than sensitivity of analysis.

a Milk produced in local dalries but sold by major distributors.

b No sample.

TABLE 6

RADIOACTIYITY OF 1967 AGRICULTURAL PRODUCTS

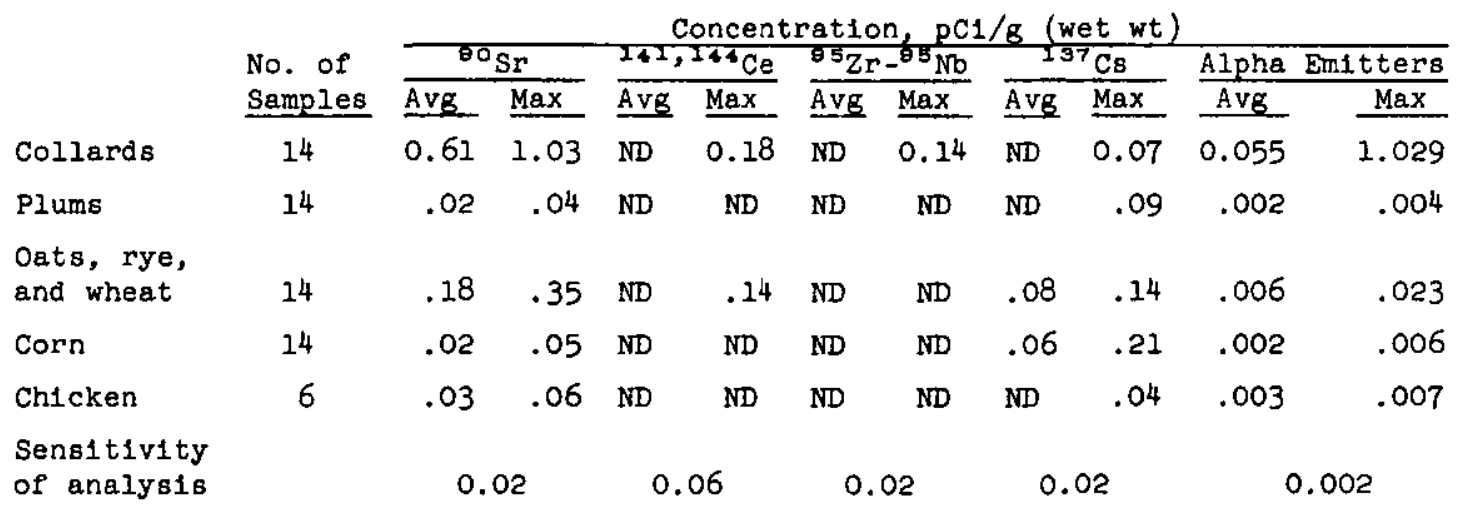

ND Less than sensitivity of analysis. 
TABLE 7

RADIOACTIVITY IN PUBLIC WATER SUPPLIES $\mathrm{pC} 1 / \mathrm{I}$

Alpha Emitters MPC : 10 Nonvolatile Beta Emitters MPC : 3000

Sensitivity of Analysis: 0.2 Sensitivity of Analys1s: 4.0

Alken

oct

oct

0.6

ND

Allendale

0.2

7

Augus ta

0.3

5

Barnwell

0.5

5

Bath

0.9

ND

Blackville

0.4

5

Clearwater

ND

ND

Jackson

4.2

10

Langley

1.6

5

New Ellenton

2.3

North Augusta

2.2

Sardis

ND

0.6

2.1

1.2

$\overline{\mathrm{ND}}$ Less than sensitivity of analysis. 
TABLE 8

AVERAGE CONCENTRATION OF RADIONUCLIDES

IN SAVANNAH RTVER WATER

Concentration, $\mathrm{pCi} / \mathrm{I}$

\begin{tabular}{|c|c|c|c|c|}
\hline Rad1onuclide & $\begin{array}{c}\text { Sensitivity of } \\
\text { Analysis } \\
\end{array}$ & $\begin{array}{l}3 \text { Miles Upstream } \\
\text { from Plant } \\
\text { (control) }\end{array}$ & $\begin{array}{l}10 \text { M1les Downstream } \\
\text { from Plant (Hwy 301) }\end{array}$ & $\begin{array}{c}\text { Percent of MPC } \\
\text { at } \\
\text { H1ghway } 301 \\
\end{array}$ \\
\hline${ }^{3} \mathrm{H}$ & 600 & 800 & 7,400 & 0.25 \\
\hline $103,108_{\mathrm{Ru}}$ & 3.2 & $\mathrm{ND}$ & $\mathrm{ND}$ & $<0.03$ \\
\hline $141,144 \mathrm{Ce}$ & 2.5 & ND & ND & $<0.02$ \\
\hline $134,137 \mathrm{Cs}$ & 0.6 & ND & 1.6 & $<0.01$ \\
\hline${ }^{23}{ }^{9} \mathrm{~Np}$ & 2.2 & $\mathrm{ND}$ & 1.7 & $<0.002$ \\
\hline $14{ }^{\circ} \mathrm{Ba}-{ }^{14}{ }^{\circ} \mathrm{La}$ & 1.6 & $\mathrm{ND}$ & $\mathrm{ND}$ & $<0.01$ \\
\hline${ }^{85} \mathrm{Zr}-{ }^{85} \mathrm{Nb}$ & 0.5 & ND & $\mathrm{ND}$ & $<0.001$ \\
\hline${ }^{51} \mathrm{Cr}$ & 4.3 & $\mathrm{ND}$ & 6.7 & 0.0003 \\
\hline${ }^{89} \mathrm{Sr}$ & 0.3 & ND & 1.5 & 0.05 \\
\hline${ }^{131} \mathrm{I}$ & 0.5 & $\mathrm{ND}$ & 0.7 & 0.23 \\
\hline${ }^{\circ} \mathrm{Sr}$ & 0.01 & 0.6 & 1.0 & 0.25 \\
\hline${ }^{80} \mathrm{Co}$ & 1.4 & ND & ND & $<0.003$ \\
\hline${ }^{85} \mathrm{Zn}$ & 1.1 & $\mathrm{ND}$ & $\mathrm{ND}$ & $<0.001$ \\
\hline${ }^{54} \mathrm{Mn}$ & 0.4 & $\mathrm{ND}$ & $\mathrm{ND}$ & $<0.0004$ \\
\hline
\end{tabular}

ND Less than sensitivity of analysis. 